\title{
Pengaruh inflasi dan pendidikan terhadap pengangguran dan kemiskinan
}

\author{
Edyson Susanto ${ }^{1}$, Eny Rochaida ${ }^{2}$, Yana Ulfah $^{3}$ \\ Magister Ilmu Ekonomi, Fakultas Ekonomi dan Bisnis Universitas Mulawarman, Samarinda. \\ ${ }^{1}$ Email: edyson.susanto@mhs.feb.unmul.ac.id \\ ${ }^{2}$ Email: eny.rochaida@ feb.unmul.ac.id \\ ${ }^{3}$ Email: yana.ulfah@feb.unmul.ac.id
}

\begin{abstract}
Abstrak
Tujuan penelitian ini adalah untuk mengetahui dan menganalisis pengaruh inflasi dan tingkat pendidikan terhadap pengangguran dan kemiskinan di Kota Samarinda. Penelitian ini menggunakan data sekunder dengan Path Analisis. Kesimpulan hasil penelitian adalah sebagai berikut: (1) Inflasi berpengaruh langsung dan signifikan terhadap pengangguran di Kota Samarinda; (2) Pendidikan berpengaruh langsung terhadap Pengangguran di Kota Samarinda; (3) Inflasi berpengaruh tidak langsung dan tidak signifikan terhadap kemiskinan di Kota Samarinda; (4) Inflasi berpengaruh tidak langsung namun tidak signifikan terhadap kemiskinan melalui pengangguran di Kota Samarinda.
\end{abstract}

Kata Kunci: Inflasi; tingkat pendidikan; pengangguran; kemiskinan

\section{Influence of inflation and education on unemployment and poverty}

\begin{abstract}
The purpose of this study is to investigate and analyze the effect of inflation and the level of education of the unemployment and proverty in Samarinda City. This research using secondary data with Path Analysis.The conclusion of this study are as follow: (1) Inflation has a significant direct effect on unemployement in the Samarinda City; (2) Education level is direct effect on unemployement in Samarinda City; (3) Inflation is significant and direct effect on poverty in Samarinda City; (4) Inflation is has in direct effect and not significant on poverty throught unemployement in Samarinda City.
\end{abstract}

Keywords: Inflation; education level; unemployment; poverty 


\section{PENDAHULUAN}

Pembangunan dilaksanakan masyarakat untuk mewujudkan kemakmuran masyarakat melalui pengembangan perekonomian mengatasi berbagai permasalahan pembangunan dan sosial kemasyarakatan seperti pengangguran dan kemiskinan. Proses pembangunan memerlukan pendapatan nasional yang tinggi dan pertumbuhan ekonomi yang cepat. Pertumbuhan ekonomi merupakan indikator untuk melihat keberhasilan pembangunan dan merupakan syarat utama bagi pengurangan tingkat kemiskinan.

Meningkatkan kegiatan perekonomian dan menciptakan lapangan pekerjaan yang lebih luas serta menurunkan tingkat kemiskinan dan menata kehidupan yang layak bagi seluruh rakyat yang pada akhirnya akan mewujudkan kesejahteraan penduduk Indonesia adalah merupakan tujuan dari pembangunan nasional.

Kemiskinan merupakan salah satu penyakit dalam ekonomi, sehingga harus disembuhkan atau paling tidak dikurangi. Permasalahan kemiskinan memang merupakan permasalahan yang kompleks dan bersifat multidimensional. Oleh karena itu, upaya pengentasan kemiskinan harus dilakukan secara komprehensif, mencakup berbagai aspek kehidupan masyarakat, dan dilaksanakan secara terpadu. Istilah kemiskinan muncul ketika seseorang atau sekelompok orang tidak mampu mencukupi tingkat kemakmuran ekonomi yang dianggap sebagai kebutuhan minimal dari standar hidup tertentu.

Upaya menurunkan tingkat pengangguran dan menurunkan tingkat kemiskinan adalah sama pentingnya. Secara teori jika masyarakat tidak menganggur berarti mempunyai pekerjaan dan penghasilan, dan dengan penghasilan yang dimiliki dari bekerja diharapkan dapat memenuhi kebutuhan hidup. Jika kebutuhan hidup terpenuhi, maka tidak akan miskin.

Data PDRB selain digunakan untuk mengetahui perkembangan maupun pertumbuhan ekonomi yang terjadi disuatu daerah pada periode tertentu, juga digunakan untuk mengetahui peranan dan potensi ekonomi di masing-masing kabupaten/kota. (BPS Samarinda, Kaltim, 2014).

Pertumbuhan ekonomi di propinsi Kalimantan Timur berdasarkan data BPS propinsi Kalimantan timur dalam tiga tahun terakhir yaitu pada tahun 2010 dari angka 7,28 persen turun menjadi 6, 35 persen pada tahun 2011, kemudian kembali turun pada tahun 2012 menjadi 5, 60 persen dan terjadi kenaikan menjadi 9,65 persen pada tahun 2013. Turun naiknya pertumbuhan ekonomi Provinsi Kalimantan Timur dari tahun 2010 sampai dengan 2013 secara rata-rata tidak memenuhi target pertumbuhan ekonomi daerah dengan nilai 4 sampai dengan 6 persen.

Masih berdasarkan data dari BPS Provinsi Kalimatan Timur untuk tingkat pengangguran dari tahun 2010 sebesar 10,10 persen, pada tahun 2011 turun menjadi 9,84 persen, kemudian terjadi penurunan lagi pada tahun 2012 menjadi 8,90 persen, terus turun pada tahun 2013 menjadi 7,94 persen. Menurut Sukirno (2010 : 9) negara dianggap mencapai tingkat penggunaan tenaga kerja penuh apabila tingkat pengangguran kurang dari 4 persen, jadi jika dihubungkan dengan keadaan tingkat pengangguran yang ada di Kalimantan Timur maka masih tergolong tinggi.

Pertumbuhan ekonomi Kota Samarinda jika dilihat berdasarkan harga berlaku PDRB Kota Samarinda meningkat dari tahun sebelumnya, jika pada tahun 2012 nilai PDRB sebesar 41.242.818 juta rupiah meningkat menjadi 44.242.919 juta rupiah pada tahun 2013. Sedangkan berdasarkan harga konstan tahun 2012 juga mengalami peningkatan yang sangat signifikan, dari 35.711 .573 juta rupiah pada tahun 2012 menjadi 37.437.485 juta rupiah pada tahun 2013. Tingkat harga yang terus bertambah menyebabkan pertambahan pada harga berlaku lebih besar dari pada harga konstan. (BPS Samarinda, Kaltim 2014).

\section{Tinjauan Pustaka \\ 1) Kemiskinan}

Pengertian kemiskinan dalam arti luas adalah keterbatasan yang disandang oleh seseorang, sebuah keluarga, sebuah komunitas, atau bahkan sebuah Negara yang menyebabkan ketidaknyamanan dalam kehidupan, terancamnya penegakan hak dan keadilan, terancamnya posisi tawar (bargaining) dalam pergaulan dunia, hilangnya generasi, Serta suramnya masa depan bangsa dan negara. Negaranegara maju yang lebih menekankan pada "kualitas hidup" yang dinyatakan dengan perubahan lingkungan hidup melihat bahwa laju pertumbuhan industri tidak mengurangi bahkan justru 
menambah tingkat polusi udara dan air, mempercepat penyusutan sumber daya alam, dan mengurangi kualitas lingkungan. Sementara untuk negara-negara yang sedang berkembang, pertumbuhan ekonomi yang relatif tinggi pada tahun 1960 sedikit sekali pengaruhnya dalam mengurangi tingkat kemiskinan.

\section{2) Penyebab Kemiskinan}

Menurut Bappenas (2010:8) dalam Hermanus (2012 : 42) Kemiskinan menurut penyebabnya terbagi menjadi 2 macam. pertama adalah kemiskinan kultural yaitu kemiskinan yang disebabkan oleh adat atau budaya suatu daerah tertentu sehingga membuatnya tetap melekat dengan kemiskinan. Kemiskinan seperti masih bisa dihilangkan atau dikurangi dengan mengabaikan faktor-faktor yang menghalangi untuk melakukan perubahan kearah tingkat kehidupan yang lebih baik. Kedua adalah kemiskinan struktural dimana kemiskinan yang terjadi disebabkan oleh ketidakberdayaan masyarakat atau kerompok tertentu terhadap system atau tatanan sosial.

\section{3) Alternatif Solusi Kemiskinan}

Menurut Effendi (2006 : 14) dalam Kustiawan (2007 : 28) mengemukakan beberapa alternativ solusi kemiskinan, yaitu:

Pertama, mendasarkan pada mobilisasi tenaga kerja yang belum digunakan (idle) dalam rumah tangga petani gurem agar tidak terjadi pembentukan modal di Pedesaan. Kedua, dapat dilakukan dengan menyusun kerangka kelembagaan di pedesaan yang memungkinkan tenaga kerja yang belum didayagunakan untuk pemupukan modal tanpa perlu menambah upah. Ketiga, menitikberatkan pada transfer sumber daya pertanian ke industri melalui mekanisme Pasar. Keempat, model pertumbuhan berbasis teknologi, menyoroti potensi pesatnya pertumbuhan dalam sektor pertanian yang dibuka dengan kemajuan teknologi dan kemungkinan menjadi sektor pemimpin.

\section{4) Pengangguran}

Pengangguran dapat dibedakan menjadi dua macam. Pertama berdasarkan kepada sumber dan penyebabnya dapat dibedakan sebagai berikut :

1) Pengangguran Normal / Friksiona

2) Pengangguran Siklikal

3) Pengangguran Struktural

4) Pengangguran Teknologi

Kedua berdasarkan ciri pengangguran wujud yaitu :

1) Pengangguran Terbuka

2) Pengangguran Tersembunyi

3) Pengangguran Musiman

4) Setengah Menganggur

Menurut BPS, Pengangguran terbuka terdiri atas:

1) Penduduk yang sedang mencari pekerjaan.

2) Penduduk yang sedang mempersiapkan usaha.

3) Penduduk yang merasa tidak mungkin mendapat pekerjaan.

4) Penduduk yang sudah punya pekerjaan

\section{5) Inflasi}

Salah satu peristiwa moneter yang sangat penting dan yang dijumpai di hampir semua negara di dunia adalah inflasi. Definsi singkat dari inflasi adalah kecendrungan dari harga-harga untuk naik secara umum dan terus-menerus. Kenaikan dari satu atau dua barang saja tidak disebut inflasi, kecuali kenaikan tersebut meluas kepada (mengakibatkan kenaikkan) sebagian besar dari harga barang-barang lain. Berdasarkan dari buku karangan Sudarso (1995 : 90), menurutnya inflasi terbagi menjadi tiga jenis yaitu :

1) Inflasi Murni,

2) Semi Inflasi,

3) Inflasi Semu. 


\section{6) Pendidikan}

Pendidikan yang lebih tinggi mengakibatkan produkifitas kerja lebih baik sehingga dampaknya akan memberikan penghasilan yang lebih besar. (Simanjuntak 1998)

Rendahnya tingkat pendidikan menyebabkan pilihan pekerjaan untuk memenuhi kebutuhan hidup menjadi terbatas sehingga pilihan yang diambilpun biasanya hanya mengandalkan tenaga sehingga penghasilan menjadi ikut rendah. Dari hasil penelitian Kuncoro dalam Subli (2005 : 26) yang memmberikan pilihan profesi dengan besarnya penghasilan yang didapatkan dimana orang yang bekerja sebagai petani mempunyai penghasilan 4, $82 \%$, orang bekrja sebagai karyawan baik bidang jasa maupun produksi dan penjualan mempunyai penghasilan sebesar $7-9 \%$ sedangkan yang bekerja sebagai manager dan pengusaha mempuyai penghasilan sebesar $35 \%$. Dari hasil penelitian tersebut maka dapat diambil kesimpulan bahwa pekerjaan dengan tingkat pendidikan yang lebih tinggi akan memberikan penghasilan yang lebih besar.

\section{Hubungan Antar Variabel}

\section{1) Inflasi dan Kemiskinan}

Dalam penelitian ini menganalisis pengaruh inflasi dan pengangguran terhadap kemiskinan di perkotaan Indonesia, dengan menggunakan dua jenis data yaitu data yang dipublikasikan oleh BPS dan data yang diolah oleh LPEM UI. Hasil yang diperoleh memperlihatkan bahwa inflasi dan pengangguran bersama-sama dengan variabel lain yaitu rasio antara garis kemiskinan dengan pendapatan rata-rata, tingkat kemiskinan periode sebelumnya, variabel-variabel demografis serta rasio gini memberikan pengaruh yang signifikan terhadap tingkat kemiskinan, baik terhadap head-count poverty, poverty gap maupun squared poverty gap. Secara lebih spesifik, pengangguran memberikan pengaruh yang signifikan dan positif terhadap tingkat kemiskinan sedangkan inflasi memperlihatkan pengaruh yang cenderung tidak konsisten dengan tingkat signifikansi yang lebih rendah. Jika menggunakan data BPS terlihat bahwa inflasi memberikan pengaruh yang cukup signifikan, tetapi bila menggunakan data alternatif terdapat kecenderungan inflasi memberikan pengaruh yang tidak signifikan. Secara implisit juga memperlihatkan kompleksnya masalah kemiskinan di Indonesia.

\section{2) Inflasi dan Pengangguran}

Tingginya tingkat inflasi menyebabkan harga barang domestic relatif lebih mahal dibanding dengan harga barang impor. Pertumbuhan ekonomi tanpa diikuti dengan penambahan tenaga kerja akan mengakibatkan ketimpangan dalam pembagian dari penambahan pendapatan tersebut (ceteris paribus) yang pada akhirnya akan menimbulkan dampak kondisi pertumbuhan ekonomi dimana tingkat lasikemiskinan yang tinggi. (Tambunan, 2009 : 32) Menurut Samuelson dan Nordhaus (2004 : 287) dalam Hermanus (2012 : 46) Hukum Okun menyatakan bahwa apabila terjadi penurunan PDB 2 persen PDB secara relatif terhadap PDB potensial akan maka akan terjadi kenaikan tingkat pengangguran sebesar satu persen. Menurut Mankiw (2007 : 251) dalam Hermanus (2012 : 47) penurunan pada produksi barang dan jasa yang terjadi selama masa resesi selalu berkaitan dengan peningkatan jumlah pengangguran.

\section{3) Hubungan Pendidikan dengan Pengangguran}

Dalam upaya mencapai pembangunan ekonomi yang berkelanjutan (Sustainable Development), sektor pendidikan memainkan peranan sangat strategis yang dapat mendukung proses dan aktivitas ekonomi lainnya. Dalam konteks ini, pendidikan dianggap sebagai alat untuk mencapai target yang berkelanjutan, karena dengan pendidikan aktivitas pembangunan dapat tercapai, sehingga peluang untuk meningkatkan kualitas hidup di masa depan akan lebih baik.

\section{4) Pendidikan dan Kemiskinan}

Pendidikan berperan penting dalam kesejahteraan seseorang dengan berbagai cara yang berbeda. Pendidikan dapat meningkatkan kemampuan penduduk untuk memperoleh dan menggunakan informasi, memperdalam pemahaman akan perekonomian, memperluas produktivitas, dan memberi 
pilihan kepada penduduk apakah berperan sebagai konsumen, produsen atau warganegara. Selain itu pendidikan dan distribusi pendapatan adalah mempunyai kolerasi yang positif dengan penghasilannya selama hidup seseorang. Korelasi ini dapat dilihat terutama pada seseorang yang dapat menyelesaikan sekolah tingkat lanjutan dan universitas, akan mempunyai perbedaan pendapatan 300 persen sampai dengan 800 persen, dengan tenaga kerja yang hanya menyelesaikan sebagian ataupun seluruh pendidikan tingkat sekolah dasar. Karena tingkat penghasilan sangat dipengaruhi oleh lamanya tahun memperoleh pendidikan, jelas ketimpangan pendapatan yang besar tersebut akan semakin besar. (Gaiha 1993 : 76)

\section{5) Pengangguran dan Kemiskinan}

Arsyad (1997 : 73) menyatakan bahwa ada hubungan yang erat sekali antara tingginya tingkat pengangguran dan kemiskinan. Bagi sebagian besar masyarakat, yang tidak mempunyai pekerjaan tetap atau hanya part-time selalu berada diantara kelompok masyarakat yang sangat miskin. Masyarakat yang bekerja dengan bayaran tetap di sektor pemerintah dan swasta biasanya termasuk diantara kelompok masyarakat kelas menengah keatas. Setiap orang yang tidak mempunyai pekerjaan adalah miskin, sedangkan yang bekerja secara penuh adalah orang kaya. Karena kadangkala ada juga pekerja diperkotaan yang tidak bekerja secara sukarela karena mencari pekerjaan yang lebih baik dan yang lebih sesuai dengan tingkat pendidikannya. Mereka menolak pekerjaan-pekerjaan yang mereka rasakan lebih rendah dan mereka bersikap demikian karena mereka mempunyai sumber-sumber lain yang bisa membantu masalah keuangan mereka. Orang-orang seperti ini bisa disebut menganggur tetapi belum tentu miskin. Sama juga halnya adalah, banyaknya induvidu yang mungkin bekerja secara penuh perhari. Tetapi tetap memperoleh pendapatan yang sedikit. Banyak pekerja yang mandiri disektor informal yang bekerja secara penuh tetapi mereka sering masih tetap miskin.

\section{METODE}

Data penelitian ini merupakan data sekunder dengan menggunakan data time series dimana tahun analisis selama 10 tahun sejak tahun 2005 sampai dengan tahun 2014. Penelitian ini menggunakan variabel eksogen inflasi, pendidikan, Variabel antara (lntervening Variabel) pengangguran dan variabel endogen kemiskinan. Penelitian ini dilakukan di Kota Samarinda.

\section{Definisi Operasional}

Variabel - variabel yang diamati dalam penelitian ini dapat dijelaskan sebagai berikut:

1) Kemiskinan adalah ketidakmampuan dari sisi ekonomi untuk memenuhi kebutuhan dasar makanan dan bukan makanan yang dinyatakan dalam persentase jumlah penduduk miskin di Kota Samarinda.

2) Pengangguran adalah Tingkat pengangguran merupakan jumlah penduduk yang menganggur, yaitu penduduk yang tidak bekerja sama sekali atau bekerja kurang dari dua hari selama seminggu sebelum pencacahan dan berusaha memperoleh pekerjaan dinyatakan dalam persentase jumlah pengangguran di kota Samarinda.

3) Inflasi adalah kecendrungan naiknya harga barang dan jasa pada umumnya yang berlangsung secara terus menerus di Kota Samarinda dinyatakan dalam persentase inflasi Kota Samarinda.

4) Pendidikan adalah jumlah lulusan SLTA sederajat (SMU \& SMK) di Kota Samarinda.

\section{Jangkauan Penelitian}

Jangkauan penelitian ini adalah mengetahui dan menganalisis pengaruh inflasi, pendidikan terhadap pengangguran dan kemiskinan yang terjadi di Kota Samarinda.

\section{Data yang Diperlukan}

Data yang dibutuhkan dalam penelitian ini adalah data sekunder diantara lain :

1) Jumlah Penduduk Miskin yang ada di Kota Samarinda tahun 2005 - 2014

2) Data besarnya tingkat pengangguran yang ada di Kota Samarinda tahun 2005 - 2014.

3) Tingkat Inflasi tahun 2005 - 2014 yang ada di Kota Samarinda

4) Jumlah lulusan SLTA tahun 2005 - 2014 yang ada di Kota Samarinda. 


\section{Teknik Pengumpulan Data}

Teknik pengumpulan data menggunakan teknik library research yaitu dengan mengumpulkan data yang berhubungan dengan penelitian melalui instansi terkait seperti BPS, Bappeda, Disnakertrans, Diknas. Dengan penelitian Kepustakaan seperti media informasi seperti buku - buku referensi, jurnal, serta media internet.

\section{Analisis Data}

Metode analisis dalam penelitian ini adalah Menurut (Suliyanto 2011 : 251) dalam Hermanus (2012 : 59) analisis jalur (path analisis) digunakan untuk mengetahui dan menganalisa hubungan antar variabel dengan tujuan baik itu pengaruh langsung maupun tidak langsung.

1) Persamaan sub struktur -1

$\mathrm{Y} 1=\rho \mathrm{Y} 1 \mathrm{X} 1+\rho \mathrm{Y} 1 \mathrm{X} 2+$ Ci Menurut Suliyanto (2011 : 251) dalam Hermanus (2012: 59) untuk mengetahui pengaruh langsung dari variabel tingkat inflasi (X1), variabel pendidikan (X2) terhadap pengangguran (Y1)

Dimana:

Y1 = Tingkat Pengangguran

$\mathrm{X} 1$ = Inflasi

$\mathrm{X} 2$ = Pendidikan

$\rho \quad=$ Koefisien Jalur

$\epsilon \quad=$ Residu

2) Persamaan sub-struktur - 2

$\mathrm{Y} 2=\rho \mathrm{Y} 2 \mathrm{X} 1+\rho \mathrm{Y} 2 \mathrm{X} 2+\rho \mathrm{Y} 2 \mathrm{Y} 1+\epsilon 2$

Untuk mengetahui pengaruh langsung dari variabel tingkat inflasi (X1), variabel tingkat pendidikan (X2) dan variabel pengangguran (Y1) terhadap kemiskinan (Y2)

Dimana :

$\mathrm{Y} 2$ = Kemiskinan

Y1 = Tingkat Pengangguran

$\mathrm{X} 1=$ Inflasi

$\mathrm{X} 2$ = Pendidikan

$\rho \quad=$ Koefisien Jalur

$\epsilon \quad=$ Residu

\section{HASIL DAN PEMBAHASAN}

Penelitian yang dilaksanakan ini merupakan penelitian empiris dengan mengunakan data time series yang didapatkan berdasarkan informasi resmi dari pemerintah seperti data pertumbuhan Tingkat Inflasi, tingkat pendidikan, pengangguran dan kemiskinan yang ada di Kota Samarinda dalam kurun waktu 10 tahun mulai dari tahun 2005 sampai dengan tahun 2014. Adapun maksud dan tujuan penelitian adalah untuk mengetahui sejauh mana pengaruh langsung dan tidak langsung serta kontribusi dari Inflasi kumulatif (X1) dan tingkat pendidikan (X2) terhadap pengangguran (Y1) dan pengaruhnya terhadap \% penduduk miskin terhadap jumlah penduduk (Y2). variabel bebas dalam penelitian ini adalah Inflasi dan tingkat pendidikan sedangkan variabel terikatnya adalah pengangguran dan kemiskinan. Yang menjadi dasar perhitungan koefisien jalur dalam penelitian ini adalah analisis korelasi dan regresi dan dalam perhitungan analisis digunakan program Path analisis.

Dari hasil analisis diatas maka model persamaan regresi sub struktur 1 menjadi : $\mathrm{Y} 1=-2,222 \mathrm{X} 1$ $+2,095 \mathrm{X} 2$ Dimana Y1 adalah pengangguran X1 pertumbuhan inflasi berpengaruh negatif terhadap Y1 pengangguran dengan nilai koefisien sebesar -2,222 X2 tingkat pendidikan berpengaruh positif terhadap Y1 pengangguran dengan dengan nilai koefisien sebesar 2,095

\section{Perhitungan Pengaruh Diagram Jalur}

Besaran pengaruh dihitung dengan menggunakan analisa jalur (path analysis) mediated path modelsebagai berikut: 
1) Pengaruh Langsung (Direct Causal Effect)

Analisa pengaruh langsung dari estimasi model sub struktur 1 dan sub struktur 2 adalah sebagai berikut:

a) Inflasi (X1) berpengaruh langsung terhadap pengangguran (Y1) sebesar -2,222,

b) Tingkat pendidikan (X2) berpengaruh langsung terhadap pengangguran (Y1) sebesar 2,095,

c) Pertumbuhan inflasi (X1) berpengaruh langsung terhadap kemiskinan (Y2) sebesar -0,817,

d) Pengangguran (Y1) berpengaruh langsung terhadap kemiskinan (Y2) sebesar - 0,155

2) Pengaruh tidak langsung (lndirect Causal Effect)

S-ebagaimana hipotesis dalam peneritian ini, bahwa variabel inflasi (X1), tingkat pendidikan (X2), pengangguran (Y1) terhadap variabel kemiskinan (Y2), yaitu dimediasi atau disalurkan melalui variabel pengangguran (Y1) Besarnya berpengaruh tidak langsung tersebut adalah sebagai berikut.

a. Inflasi (X1) berpengaruh tidak langsung terhadap terhadap kemiskinan (Y2) melalui pengangguran (Y1) sebesar $-2,222 \times-0,155=0,344$

b. Tingkat pendidikan (X2) berpengaruh tidak langsung terhadap terhadap kemiskinan (Y2) melalui pengangguran (Y1) sebesar 2,095 x $-0,155=-0,325$

3) Pengaruh Total (Total Effect)

a. Pengaruh variabel inflasi (X1) terhadap Kemiskinan (Y2) melalui pengangguran (Y1) sebesar $-0,817+0,344=-0,473$ Pengaruh variabel

\section{SIMPULAN}

Berdasarkan dari hasil analisis dan pembahasan yang telah dikemukakan pada bab sebelumnya dapat diuraikan beberapa hal yang berkaitan dengan penelitian ini sebagaimana hal berikut:

1. Inflasi berpengaruh langsung dan signifikan terhadap pengangguran di Kota Samarinda.

2. Pendidikan berpengaruh langsung terhadap Pengangguran di Kota Samarinda, meningkatnya penduduk yang tamat SMA dari tahun ke tahun namun lapangan pekerjaan semakin sulit di peroleh sehingga penduduk yang mempunyai tingkat pendidikan SMA sederajat semakin bersaing ketat dalam memperoleh pekerjaan.

3. Inflasi berpengaruh tidak langsung dan tidak signifikan terhadap kemiskinan di Kota Samarinda.

4. Inflasi berpengaruh tidak langsung namun tidak signifikan terhadap kemiskinan melalui pengangguran di Kota Samarinda.

\section{DAFTAR PUSTAKA}

Alghofari, Farid, (2010) Analisis Tingkat Pengangguran Di Indonesia Tahun 1980-2007. Jurnal Universitas Diponegoro Semarang

Anonim, 2013 Kota Samarinda dalam Angka Tahun 2010, Badan Pusat Statistik, Kota Samarinda

Anonim, 2013 Kota Samarinda dalam Angka Tahun 2011, Badan Pusat Statistik, Kota Samarinda

Anonim, 2013 Kota Samarinda dalam Angka Tahun 2012, Badan Pusat Statistik, Kota Samarinda

Anonim, 2013 Kota Samarinda dalam Angka Tahun 2013, Badan Pusat Statistik, Kota Samarinda

Arsyad L, (1997), Ekonomi Pembangunan. STIE YKPN, Yogyakarta.

Akin, Emmanuel, (2013) Determinan tingkat kemiskinan penduduk Kutai Barat. Tesis Pascasarjana Universitas Mulawarman Samarinda

Boediono. (1981). Teori Pertumbuhan Ekonomi. Yogyakarta. BPFE. UGM

Boediono, (2000). Ekonomi Internasional. Yogyakarta. BPFE. UGM

Bappenas. "Penaggulangan Kemiskinan" http://www.Bappenas.go.id.2010

Effendi, Aji Sofyan, 2006. Strategi Penanggulangan Kemiskinan, Kongres Ilmu Pengetahuan Wilayah Kalimantan Timur, Samarinda

Gaiha, R. 1993. Design Of Poferty Allevation Strategy In Rural Areas. Fao. Roma 
Gujarti, Damodar. (1999). Ekonometrika Dasar, terjemahan Sumarsono Zain. Jakarta Erlangga

Ghozali, Imam. 2001. Aplikasi Analisis Multivariate Dengan Program SPSS. Semarang: Badan Penerbit Universitas Diponegoro

Gamin, Sukarni, (2009), Faktor yang mempengaruhi pendapatan dan kemiskinan. masyarakat. Tesis Pascasarjana Universitas Mulawarman Samarinda

Hermanus, (2012), Pengaggurandan kemiskinan ditinjau dari pertumbuhan ekonomi dan inflasi di Provinsi Kalimantan Timur. Tesis Pascasarjana Universitas Mulawarman Samarinda.

Irawan dan Suparmoko. (1999). Ekonomi Pembangunan dan Perencanaan, Raja Grafindo Persada, Jakarta.

Jhingan, M.L 2004.EkonomiPembangunan dan Perencanaan, Raja Garfindo Persada Jakarta.

Kuncoro, Mudrajad, (1997), Ekonomi Pembangunan, Teori Masalah dan Kebijakan, Cetakan Pertama, Unit Penerbit dan Percetakan akademi manajemen perusahaan YKPN, Yogyakarta

Kuncoro, Mudrajad, (2004), Otonomi dan Pembangunan Daerah: Reformasi Perencanaan Strategi, dan Peluang, Erlangga, Jakarta

Kuncoro, Mudrajad, (2006), Strategi: Bagaimana Meraih Keunggulan Kompetitif. Jakarta: Erlangga

Kustiawan, Andriawan, (2007) Pengaruh Faktor-Faktor Internal Terhadap Kemiskinan Masyarakat kelurahan Sidomulyo Kecamatan Samarinda Ilir. Tesis Megister Ilmu Ekonomi Unmul, Samarinda

Listyaningsih, (2004), Dinamika Kemiskinan di Yogyakarta. Pusat Studi Kependudukan dan Kebijakan Universitas Gadjah Mada dan Patnership for Economic Growth (PEG), USAID. Yogyakarta

Mankiw, Gregory N. (2000). Teori Makro Ekonomi, Saduran Nurmawan. Jakarta. Erlangga

Mankiw, Gregory N. (2007), Mikroekonomi, Edisi Keenam. Jakarta. Erlangga

Nurske, Ragnar, (1953), Problems Of Capital Formation in Underdeveloped Countries. Oxford Basis Blackwell

Pantjar Simatupang dan Saktyanu K. Dermoredjo, 2003, Produksi Domestik Bruto, Harga, dan Kemiskinan, Media Ekonomi dan Keuangan Indonesia.

Pratama, Yogi C., (2014), Analisis Faktor-faktor yang Mempengaruhi Kemiskinan Di Indonesia. Jurnal Bisnis dan Manajemen, UIN Syarif Hidayatullah Jakarta.

Sukirno, Sadono. 1983. Ekonomi Pembangunan. Jakarta: LP Universitas Indonesia

Sukirno, Sadono. 2000, Makro EkonomiModern, Penerbit PT Raja Grafindo Persada, Jakarta

Sukirno, Sadono. 2011, Makroekonomi Teori Pengantar Edisi Ketiga, Jakarta. Rajawali Pers

Sajogjo, 1982. Garis Kemiskinan dan Kebutuhan Minimum Pangan, Dalam Mencari Bentuk Ekonomi Indonesia, Gramedia, Jakarta

Sumitro Djojohadikusumo, 1995, Perkembangan Pemikiran Ekonomi Dasar

Sugiyono, (2012), Metode Penelitian Bisnis. Bandung: Alfabeta

Sarwoko. 2005. Dasar - dasar Ekonometrika. Penerbit Andi. Yogyakarta

Suliyanto. 2011. Ekonometrika Terapan: Teori Dan Aplikasi Dengan SPSS. Yogyakarta: Andi

Subli, (2005), Hubungan kemiskinan dan factor-faktor penyebabnya pada masyarakat desa kembang Janggut dan Kota Bangun II Kutai Kartanegara. Tesis Pascasarjana Universitas Mulawarman Samarinda 
Sahadi, (2009), Beberapa factor yang mempengaruhi kemiskinan di provinsi Kalimantan Timur. Tesis Pascasarjana Universitas Mulawarman Samarinda Simanjuntak, Payaman J, (1998), Pengantar Ekonomi Sumber Daya Manusia. Jakarta: Lembaga Penerbitn Fakultas Ekonomi UI.

Suparlan, Parsudi (1984) Kemiskinan di Perkotaan; Buku Obor; Jakarta, Penerbit Sinar Harapan

Sukirno, Sadono, (2010), Makroekonomi. Teori Pengantar. Edisi Ketiga. PT. Raja Grasindo Persada. Jakarta

Sukirno, Sadono. (2005), Mikro Ekonomi Teori Pengantar Edisi Ketiga. PT. Rajagrafindo Persada : Jakarta

Samuelson dan Nordhaus, (2004) Ilmu Makroekonomi. Edisi Ketujuhbelas. Jakarta: PT. Media Global Edukasi.

Sarwono, (2012), Metode Penelitian Kuantitatif dan Kualitatif, Yogyakarta; Graha Ilmu

Todaro, Michael P. (1994). Pembangunan Ekonomi di Dunia Ketiga. Jilid I. Edisi Keempat. Jakarta. Erlangga

Todaro, Michael P. (2000). Pembangunan Ekonomi di Dunia Ketiga. Terjemahan Haris Munandar. Jakarta. Erlangga.

Tambunan, Tulus T.H. (2001). Transformasi Ekonomi di Indonesia. Jakarta. Salemba

Tambunan, Tulus T.H. (2009), UMKM di INDONESIA, Ghalia Indonesia, Bogor

Todaro, Michael P, (2003), Pembanguunan Ekonomi di Dunia Ketiga. Alih Bahasa: Aminuddin Dan Drs. Mursid. Jakarta: Ghalia Indonesia

Todaro, Michael P. (2000). Economic Development, Seventh Edition, Ney York University, Addison Mesley

Widarjono, Agus. (2005) Ekonometrika, Teori dan Aplikasi. Yogyakarta: Ekonisia

Y. P Veneris And F. D Sebold, 1997. Macroeconomic Model And Policy, John Wiley \& Sons Inc, New York. 